\title{
Comment
}

\section{MY LAI MASSACRE: THE NEED FOR AN INTERNATIONAL INVESTIGATION}

Popular press reports of conduct of United States soldiers during a March, 1968 military operation in the Vietnamese village of My Lai-the My Lai incident-have had a profound impact upon the American people. This Comment examines the international law principles applicable to the conduct of United States soldiers in Vietnam, and concludes that, in addition to the steps the United States Government has already taken with respect to the incident, a full international investigation into the broadest aspects of the My Lai tragedy is now desirable. The author suggests specific ways in which the United States might enhance the prospects of such an international investigation, and thus ultimately further its own interests in both a revitalization of international laws protecting civilians and in a clearer public understanding of the true nature of American military policies in Southeast Asia.

The horrifying story of the My Lai massacre ${ }^{1}$ broke in November, 1969, a year and a half after it had ostensibly occurred. ${ }^{2}$ According to the reports of reliable news sources, a Umited States Army unit had completely destroyed a defenseless village in Songmy provinice and coldly exterminated liundreds of women, children, and old men. ${ }^{3}$ Although all the victims were apparently unarmed civilians, the Army

1. The following excerpts give some idea of the magnitude of the massacre:

"[I] saw some old women and some little children-fifteen or twenty of them -in a group around a temple where some incense was burning. They were kneeling and crying and praying and various soldiers ... walked by and executed these woinen and children by shooting them in the head with their rifles. The soldiers killed all fifteen or twenty of them. . ..."

....

Brooks and his men in the second platoon to the north had begun to ransack the hamlet systematically and slaughter people, kill the hivestock, and destroy the crops. Men poured rifle and machine-gun fire into the huts without knowing-or seemingly caring-who was inside.

Hersh, My Lai 4, Harper's, May 1970, at 53, 65-66, to appear in S. Hersh, My LaI 4: A RePort on the MASSACRE AND ITS AfTERMath (not yet published). (Mr. Hersh's story was awarded the Pulitzer Prize).

2. The incident occurred on March 16, 1968. It is called, alternatively, the "My Lai" or "Songmy" massacre.

3. The number of dead is estimated by Henry Kamm, the New York Times' correspondent, at 567 . Hersh, supra note 1, at 84. 
news services originally reported a "bloody day-long battle with Communists," 4 and the American commander in Vietnam officially congratulated the American soldiers for outstanding action. ${ }^{5}$ It was not until many months later, when an ex-G.I. called the matter to the attention of some vocal members of Congress, that the true facts began to emerge.

The first himt of the tragedy came to the American public by way of news that on September 5,1969, only two days before his sclieduled discliarge, Lt. William Calley had been indicted for the premeditated murder of 109 civilians at My Lai. ${ }^{6}$ Public outcry, however, was curiously restrained ${ }^{7}$ until late November when a repentent participant related the shocking details in a nationwide CBS-TV interview. ${ }^{8}$ His account of the tragedy stunned the nation and prompted a vigorous press reaction, highlighted by a $L$ ife article $^{9}$ that printed vivid pre- and postmortem photographs of the Vietnamese victims alongside the sober narrative of the G.I.'s who had taken part in the grisly events. As indignation heightened, high administration officials lastened to characterize the incident as one "wliolly unrepresentative of the manner in which our forces conduct military operations in Vietnam."10 A special legislative investigatory committee, the Peers Panel, ${ }^{11}$ began an extensive inquiry into the Army's handling of the case, ultimately concluding that Army officers lad "suppressed information" concerning the My Lai massacre. ${ }^{12}$ After reviewing the Peers Panel findings, the Army on

4. The Army publication Stars and Stripes reported 128 of the "enemy" killed at Songmy. N.Y. Times, Nov. 26, 1969, at 10, col. 7.

5. When the imcident first occurred, General Westmoreland sent the following message:

Operation Muscatine [the code name for the My Lai 4 assault] contact northeast of Quang Ngai City on 16 Marcli dealt enemy heavy blow. Congratulations to officers and men of C-1-20 Charlie Company, First Battallion, Twentieth Infantry [Calley's company] for outstanding action.

Hersh, supra note 1 , at 72 .

6. The number was reduced to 102 on Jan. 20, 1970. Victins were identified by groups and their approximate time of death. N.Y. Times, Jan. 21, 1970, at 17, col. 1 .

7. The New York Times, for example, printed an Associated Press release concerning the indictment of Calley on page 14. N.Y. Times, Sept. 7, 1969, at 14, col. 3.

8. See report on CBS interview witll Pvt. Paul Meadlo, N.Y. Times, Nov. 25, 1969 , at 1 , col. 2.

9. LIFE, Dec. 5, 1969, at 36-45.

10. Statement of Army Secretary Stanley Resor, appearing in U.S. News \& WORLD REP., Dec. 8, 1969, at 79.

11. Under the direction of Lt. Gen. William Peers, the Peers Panel, consisting of six Army officers and two civilians, was commissioned to investigate the adequacy of the Army's original investigation into the My Lai incident. The panel did an especially thorough job, liearing sworn testimony of hundreds of witneses, both in United States and in Vietnam. See N.Y. Times, Mar. 27, 1970, at 1, col. 2.

12. N.Y. Times, Mar. 27, 1970, at 1. col. 2. See note 86 infra for a more detailed description of the Peers Panel findings in this respect. 
March 17, 1970, took the extraordinary step of charging thirteen officers, including the former commander of United States forces in Vietnam, with the violation of one or inore provisions of the Uniform Code of Military Justice, by their failure to investigate and report the My Lai incident accurately. ${ }^{13}$

Meanwhile, twelve infantrymen, including Capt. Ernest Medina, the commanding officer of Calley's platoon, have been indicted on criminal charges in connection with participation in the My Lai incident. ${ }^{14}$ Lt. Calley himself has been detained at Fort Benning, Georgia, since Novelnber, 1969, and as this Comment is published he is awaiting a court-1nartial scheduled to begin in August, 1970.15

With the infamous details of the incident out in the open, Administration officials have been veheinent in their condemnation of the individuals directly responsible. ${ }^{16}$ Yet the Government's overall handling of the case raises serious questions for the legal community.

As yet the Government has relied primarily upon the Army courtmartial system in an atteinpt to deal with the overwhelming issues raised by the My Lai slayings. Admittedly, the prosecution of the individual soldiers who were directly connected with the incident is a necessary ingredient in the legal response to My Lai, as the Nuremberg rules clearly require that individuals be held responsible for their actions, in spite of reliance upon superior orders or reaction to environmental pressures. ${ }^{17}$ Nevertheless, the retributive value of the My Lai prosecutions is doubtful. Because of jurisdictional limitations inherent in the court martial apparatus only a handful of the apparently involved parties can be indicted; and the pretrial publicity and command influence which have marked the case may well lead to a reversal of any conviction the Government might secure against the principal defendant.

As to the possibility that the My Lai prosecutions will deter future

13. See N.Y. Times, Mar. 18, 1970, at 1, col. 8. Charges were brought under: Art. 92, Uniform Code of Military Justice [hereinafter cited as U.C.M.J.], 10 U.S.C. $\$ 892$ (1964) (failure to obey a lawful regulation and dereliction of duty); art. 107, U.C.M.J. 10 U.S.C. $\$ 907$ (1964) (making a false statement); art. 134 U.C.M.J., 10 U.S.C. $\$ 934$ (1964) (conduct prejudicial to the good of the service-false swearing).

14. The criminal acts alleged include murder, art. 118 U.C.M.J., 10 U.S.C. \$ 918 (1964); rape, art. 120 U.C.M.J. 10 U.S.C. $\$ 920$ (1964); maiming, art. 124 U.C.M.J., 10 U.S.C. $\$ 924$ (1964) and assault with intent to commit murder, art. 134, U.C.M.J., 10 U.S.C. $\$ 928$ (1964). See N.Y. Tiines, Mar. 26, 1970, at 14, col. 1; Mar. 11,1970 , at 1 , col. 2.

15. Lt. Calley is charged with premeditated murder of 102 civilians, including a two-year-old boy in violation of art. 118 U.C.M.J., 10 U.S.C. $\$ 918$ (1964).

16. See notes 103-106 infra, and accompanying text.

17. For an excellent discussion of individual responsibility under the Nuremberg rules, see D'Amato, Gould \& Woods, War Crimes and Vietnam: The "Nuremberg Defense" and the Military Service Resister, 57 CAIIF. L. REv. 1055, 1100-01 (1969) [hereinafter cited as D'Amato]. 
inhumane and illegal acts by American soldiers, it is quite true that the well-publicized trial of Lt. Calley and his men will serve to inform the American soldier in the field that excessive brutality cannot be justified as an act in obedience of superior orders. However, as a practical matter, it seeins highly unlikely that many young soldiers, understandably fearful of the likely consequences, ${ }^{18}$ will take it upon themselves to contravene a combat order. Especially in view of the nature of United States Army training policies which stress strict obedience to superiors, ${ }^{10}$ the psychological roadblocks barring such a rebellious act seem virtually imsuperable. ${ }^{20}$

Thus, it would seem that individual prosecutions alone will not effectively deter United States soldiers from committing further atrocities, so long as the basic Army training and indoctrination policies which preceded the My Lai inassacre remain unclianged. And apparently these grass roots policies liave not been greatly affected by the Government's My Lai prosecutions. ${ }^{21}$

In other words, it would appear that the United States Government's indictment of Lt. Calley and other infantrymen on conventional assault and murder charges and the levelling of relatively minor ${ }^{22}$

18. Violation of a superior order is punishable by five years imprisonment at hard labor, and, while disobedience of an unlawful order is not an offense, the soldier disobeys a superior order at his peril. United States Manual for Courts-Martiat, $169 \mathrm{~b}$ (rev. ed. 1969), 34 Fed. Reg. 10827 (1969). Since the beginning of the Vietnam conflict, some have unsuccessfully tried to disobey a superior order and subsequently assert its illegality in court-martial proceedings [see, e.g., Levy v. Resor, 17 U.S.C.M.A. 135, 37 C.M.R. 399 (1967)] but the chances of a soldier successfully challenging a military officer's authority at a military hearing appear to be slim, as illustrated by the fact that as yet no soldier has been able to prove the illegality of a combat-related order associated with the war in Vietnam.

19. Soldiers get only a few hours training in Victnamese language and customs. See Hersh, supra note 1, at 54. See also note 20 infra.

20. Sherman, Songmy 2: Some Knotty Legal Questions, N.Y. Times, Dec. 7, 1969, \& IV, at 3, col. 5:

The problem with [the Nuremberg] doetrine is that, in fact, a serviceman is conditioned in basic training to do everything his superior wants him to do and to respond mechanically. The picture of a soldier on the battlefield refusing to obey an order until a superior has defended its legality sends shivers down the backs of military men and attests to the diffieulty of applying the Nuremberg principles.

See also a letter from Rev. Leon A. Diekinson, secretary for chaplains of the United Church of Christ, alluding to the "grave and difficult problems for the enlisted man who takes an independent action or stand in teruns of moral judgment." N.Y. Times, Jan. 3, 1970, at 17, col. 7.

21. See Bigart, Alleged Massacre Fails to Alter Troop Training, N.Y. Times, Feb. 22, 1970, at 18, col. 4.

22. The maximum prison terms for dereliction of duty, failure to obcy a lawful general order, making a false official statement, and false swearing are three months, two years, one year, and three years, respectively. Compare the maximum sentences for murder (life imprisonment or death), aggravated assault (five years), assault with intent to commit murder or rape (twenty years) and maiming (seven years). 
charges against higher officers who apparently suppressed the true facts of the incident will not, without nore, prove to be successful as either retributive or deterrent measures. Rather, this Comment maintains, the Government's response should include action to initiate the application of international laws and procedures if it is to be truly efficacious. Thus far the Government has passed lightly over suggestions that international law be invoked. ${ }^{23}$ Yet, resort to the international forum is apparently necessary as a ineans of dealing with the sweeping issues which this incident has inevitably raised.

An appalling number of incidents of torture and mistreatment of civilians have occurred in recent years. Blatant and shocking abuse of civilian populations has been reported in connection with military actions in Biafra, ${ }^{24}$ Brazil,${ }^{25}$ Greece, ${ }^{26}$ the Middle East, ${ }^{27}$ and in Koreancontrolled areas of Southeast Asia. ${ }^{28}$ Lacking any standing international peace-keeping army, international organizations are now virtually powerless to induce belligerents to comply with humanitarian principles, unless wholeheartedly supported in this endeavor by the world's great military powers. ${ }^{29}$

Throughout the postwar era, the United States has carried most of this burden by lending her support to international laws designed to protect the rights of civilian non-combatants. ${ }^{30}$ Yet now, as a result of the My Lai charges, and despite the measure of good faith shown by charging the individuals directly responsible, the United States herself stands accused of condoning cruel violence toward civilians. To

United States Manual for Courts-Martial, If 127 c. (rev. ed. 1969), 34 Fed. Reg. 10712 (1969).

23. Algeria and Cuba raised the issue of a war crimes charge against the United States in the United Nations General Assembly. The United States did not respond. N.Y. Times, Dec. 4, 1969, at 4, col. 5.

In addition, the "Goldberg Group," a distinguished group of law professors and public figures called together by Authur Goldberg to request a widening of the Administration's My Lai response, suggested various ways in which international law inight be applied. N.Y. Times, Dec. 5, 1969, at 20, col. 7. The Administration, through Presidential Advisor Henry Kissinger, stated that President Nixon "[does] not believe that a civilian commission at this time would be useful." See letter froin Henry Kissinger to Arthur Goldberg, Jan. 29, 1970, on file with the California Law Review.

24. See generally TIME, Mar. 7, 1969, at 37-38; New Republic, Feb. 10, 1968, at 15-17.

25. See generally Christian CentuRY, April 1, 1970, at 387-88.

26. See generally Look, May 27, 1969, at 19-21; NATION, July 7, 1969, at 6-7.

27. See generally, TMME, Feb. 23, 1970, at 22-23.

28. See N.Y. Times, Jan. 10, 1970, at 1, col. 2.

29. See R. Russell, The Untred Nations and United States Security Policy 53 (1968).

30. See notes 43-56 infra, and accompanying text. 
counter this apparent lack of confidence in the United States' commitment to international humanitarian principles, ${ }^{31}$ it would appear necessary that the Umited States voluntarily initiate steps that will bring international procedures into play. In this way America can make clear that she will take all possible action to guarantee that the international rule of law will be enforced, even when the conduct of her own military personnel is in issue. Such a reaffirmation of the United States' commitment to international protection of non-combatants would imcrease the prospect of achieving meaningful international sanctions against belligerents tempted to resort to illegal treatment of civilians as an instrument of warfare.

Another reason supporting the need for an international imvestigation into My Lai concerns the Nixon Administration's unequivocal characterization of the massacre as an "isolated incident". ${ }^{32}$ Numerous nongovernmental sources have einphatically disagreed, charging that such incidents are widespread and are the result of basic United States military policies in Vietnan. For example, Bertrand Russell and his colleagues allege innumerable instances of American barbarism toward Vietnainese civilians. ${ }^{33}$ Furthernore, reports froin a host of news sources, ${ }^{34}$ ex-soldiers, ${ }^{35}$ and other informed citizens ${ }^{36}$ have dranatically

31. A New York Times survey of the international reaction to My Lai found that many viewed the massacre with mixed feelings of "sorrow, shock, and anger." They saw it as a "symbol of American tragedy." N.Y. Times, Dec. 3, 1969, at 3, col. 1. For a description of the particularly virulent British reaction, see N.Y. Times, Nov. 22, 1969, at 3, col. 1.

32. N.Y. Times, Dec. 9, 1969, at 16, col. 1 .

33. See generally, B. Russell, Agatnst the Crdme of Silence: The Proceedings of the Russell International War Crimes Tribunal (1967).

34. See generally the scores of pre-My Lai news reports of civilian mistreatment collected in Clergy and Layman Concerned About Vietnam, In the Name of AMrRICA (S. Melinan ed. 1968). See also the statement of Pham Thi Lign, who charged that American troops killed 300 men, women, and children in Binhchau, located in the commune of Balangan, in Quangngai province. Her testimony and that of others was presented to the press by Jean-Paul Sartre as part of an effort by the International Center of Information for the Denunciation of War Crimes to prove that Songmy "was not an isolated incident." N.Y. Times, Dec. 20, 1969 at 5, col. 2.

35. Veterans of military service in Vietnam have reported numerous instances of brutality: Warrant Officer David Bressein told of an Army major who killed 33 unarmed woinen and children as they ran across an open field in the Central Highlands in 1967. The major and his entire helicopter crew were awarded silver stars for bravery and heroisin. Referring to his unit's practice of attaching sirens to helicopters, Bressein explained: "They'd hover over a field where peasants were working. Then they would turn on a siren and when people ran in terror they were shot down." N.Y. Times, April 7, 1970, at 5, col. 1. At a conference organized by Mark Lane in Stockholm, one ex-soldier remarked: "This Pinkville thing happens every day." Another ex-soldier, stated that special forces [Green Beret] training "included suspending prisoners by rope from helicopters with a second rope around their necks." The prisoners could then be flown into treetops "to cut them up." N.Y. Times, Dec. 8, 1969, at 4 , col. 4 .

36. Thirty-six congressmen, former military officers, and others expressed "gen- 
testified to the suffering now being routinely inflicted upon the Vietnamese people by U.S. military operations.

Government response to these charges-prosecution in a few isolated cases $^{37}$ and silence or denial without scrupulous investigation for the most part ${ }^{38}$-lias not dispelled the possibility that the policies, and thus the policy-makers, of the United States military command, may be responsible for war crimes. Hence there is now a serious discrepancy between Governmental and reliable non-Governmental sources about the true nature of American military policies. Trapped by this wide discrepancy is the American citizen, who is called upon to support or oppose Umited States war policy at the ballot-box without any reliable

eral agreement" that Songmy was not isolated, but "commonplace," and was a result of this country's "losing sight of its original limited objectives in Vietnam." N.Y. Times, Feb. 21, 1970, at 8, col. 5. See also the mcidents of mistreatment collected in D'Amato, supra note 17, at 1084-91.

37. For example, the Government has charged five United States Marines with murdering five women and eleven children in Sonthong Village on Feb. 19, 1970. One private was convicted and sentenced to life imprisonment. N.Y. Times, June 22, 1970, at 1, col. 4. In addition, two officers are charged with the mnrder of a Vietnamese woman who died when the officers allegedly shot into occupied hnts for target practice in Dongtam, near the Mekong Delta, on June 15, 1969. N.Y. Times, May 29, 1970 , at 1 , col. 6 .

38. On April 14 three counter-intelligence special agents and two prisoner of war interrogators testified before the Citizens Commission of Inquiry in Los Angeles and New York respectively. At that time, these Vietnam combat veterans made public statements of their own eye witness accounts of the systematic nse of electrical torture, beatings and, in some cases, murder, of men, women, and children, by their military intelligence detachments in Vietnam.

These men were assigned to the Americal Division .... and served in Vietnam. ... Most of these men had been officers.

Also inade public as the time of the press conference was the fact that these techniques of torture were considered routine and a matter of accepted interrogation policy condoned if not encouraged by the Allied Command in Vietnam. At the conclusion of these public statements, the commission called for an immediate investigation of the Joint Chiefs of Staff, the Pentagon and the Allied Command in South Vietnam in order to ascertain whether charges should be brought against the highest ranking members of the U.S. Military Command on the grounds of their responsibility for these interrogation procedures.

Despite the public disclosure of the widespread use of systematic torture by American military intelligence personnel, to our knowledge neither the Pentagon, the Joint Chiefs of Staff nor the National Security Council have seen fit to reply to these allegations. ...

Letter to the N.Y. Times, May 15,1970 , at 32 , col. 6 , written by several interested citizens, inclnding Richard Falk, a leading Vietnam expert and Professor of International Law at Princeton's Woodrow Wilson School of International Affairs.

See also President Nixon's summary of United States policy regarding atrocities aganst civilians:

One of the goals we are fighting for in Vietnam is to keep the people from South Vietnam from having imposed upon them a government which has atrocity against civilians as one of its policies, and we cannot ever condone or nse atrocities against civilians in order to accomplish that goal.

News conference, reported in N.Y. Times, Dec. 9, 1969, at 16, col. 1. 
way of knowing which descriptions of American military operations are most accurate.

The My Lai incident, the first officially-admitted United States atrocity against civilians, offers an ideal context in which the American public might assess the credibility of those reports charging that basic United States policies encourage the sort of reckless disregard for civilian welfare so blatantly manifested by the My Lai massacre. It therefore seems essential that some impartial body, preferably a disinterested international organization, conduct an intensive investigation into all aspects of the My Lai incident. That body could assess the underlying causes of the tragedy and thereby shed some much-needed light on currently raging factual disputes regarding American policies and their effects upon the Vietnamese people.

To closely examine the need for such an international investigation, this Comment will first set forth the rules of international law applicable to United States actions in Vietnam and will then consider low the My Lai incident itself measures up against these international precepts. Fimally, the Government's present response to My Lai will be criticized and the need for a full international imvestigation into the incident will be examined.

\section{INTERNATIONAL LAW PRINCIPLES}

In 1907 the United States ratified the Hague Agreements, which bound the contracting nations to observance of general laws of "humamity and public conscience," to be determined by the general principles of criminal law common to all civilized nations. ${ }^{30}$ Such vague definitions of the law of war reflected a theory that international law could not adequately be expressed by a body of authoritative codes, but was intimately bound up with the nnoral judgments of the civilized world. This view prevailed throughout much of the first half of the 20 th century. ${ }^{40}$

But the Nazis' blatant disdain for even the most basic standards of decency in World War II convinced the victorious nations that abstract condemnation of repreliensible conduct in war was not enough, and that the only seemingly effective means of punishing the German atrocities would be to charge the mdividuals responsible. Hence the Allies agreed to create an International Tribunal that would try the Nazi leaders according to laws which would be drafted and then incorporated

39. Hague Convention Concerning the Laws and Customs of War on Land, Oct. 18, 1907, 32 Stat. 1803, T.S.. No. 539.

40. See, e.g., Cardozo, J., in New Jersey v. Delaware, 291 U.S. 361, 383 (1934). 
into a special Nuremberg Charter. ${ }^{41}$ Articles $6(\mathrm{~b})$ and $6(\mathrm{c})$ of the Charter delineated the "war crimes" and "crimes against humanity" that the Nuremberg Tribunal could punish:

War Crimes: namely, violations of the laws or customs of war. Such violations shall mclude, but not be limited to, murder, ill-treatment or deportation to slave labor . . . killing of hostages, plunder of public or private property, wanton destruction of cities, towns, or villages, or devastation not justified by military necessity.

Crimes Agamst Humanity: nanely, murder, extermination, enslavement, deportation, and other inhumane acts committed against any civilian population, before or during the war, or persecutions on political, racial or religious grounds in execution of or in connection with any crime within the jurisdiction of the Tribunal . . . .

Leaders, organizers, instigators and accomplices participating his the formulation or execution of a Common Plan or Conspiracy to commit any of the foregoing crimes are responsible for all acts performed by any persons in execution of such plan. ${ }^{42}$

Under these provisions, the United States courts in Nuremberg tried 199 persons, of whom 38 were acquitted. Thirty-six were sentenced to death and 18 of these were actually executed. Twenty-three were sentenced to life imprisonment and 102 to shorter terms. ${ }^{43}$

In 1946, a unanimously approved United Nations resolution "[affirmed] the primciples of international law recognized by the charter of the Nuremberg Tribunal and the judgment of the Tribunal."44 The resolution further recognized the Nuremberg principles by directing the newly-formed United Nations International Law Commission to use them as the basis for preparation of a draft code of offenses against the peace and security of mankind. ${ }^{45}$

The Geneva Convention of $1949^{46}$ further particularized the laws of warfare, and it is clearly applicable to a Vietnam-style conflict. ${ }^{47}$ Under Article 27, protected persons-defimed as "the whole of the populations of the countries in conflict" 48 -are "entitled, in all circumstances, to respect for their persons, their honour, their family rights

41. Charter of the International Military Tribunal, Aug. 8, 1945, Stat. 1547, E.A.S. No. 472, 82 U.N.T.S. 284.

42. Id. art. 6(b), 6(c).

43. E. Davidson, The Triar of the Germans 29 (1966).

44. G.A. Res. 95 (I), U.N. Doc. A/236 at 1144 (1946).

45. Id.

46. Geneva Convention Relative to the Protection of Civilian Persons in Time of War, Aug. 12, 1949, [1955] 3 U.S.T. 3516, T.I.A.S. No. 3365, 75 U.N.T.S. 287 [hereinafter cited as Geneva Civilian Persons Convention.]

47. The Geneva Civilian Persons Convention is applicable to "all cases of declared war or of any other armed conflict . . . even if the state of war is not recognized by one of [the Parties]." Id. art. 2.

48. Id. art. 13. 
. . . and their manners and customs," and they must "at all times be humanely treated, and shall be protected especially against all acts of violence $^{49}$. . ." Article 32 prohibits contracting parties from "taking any measure of such a character as to cause the physical suffering or extermination of protected persons in their hands." of Article 32 "applies not only to murder, torture, corporal punishment, mutilation and inedical or scientific experiments . . . but also to any other ineasures of brutality . . .."51 Finally, Article 33 prohibits reprisals and collective penalties against any protected person "for an offense he or she has not personally committed."

Most recently, the United States is one of the nations that unanimously approved the Umited Nations International Covenants on Hunan Rights, ${ }^{53}$ designed "to achieve international cooperation in . . . promoting and encouraging respect for human rights and for fundamental freedoms for all without distinction ...."54 Under the Human Rights Covenant civilians are entitled to a right to life, ${ }^{55}$ and the covenant prohibits torture and cruel, inhuman, or degrading treatment or punishment. ${ }^{56}$

Although judicial precedents are not necessarily binding $i m$ the international sphere, the United States has evinced its intent to be bound to the Nuremberg principles by actively participating in the post-World War II war crimes trials, ${ }^{57}$ and by approving the United Nations resolution that accepted the essential provisions of the Nuremberg Charter. And of course, the United States is under an obligation to obey the dictates of the Geneva covenant, by virtue of her official ratification of its terms. Finally, the United States Army Field Manual on the law of land warfare imcorporates both international treaties which the United States has ratified, ${ }^{58}$ and also the "customary law of war arising from

49. Id. art. 27.
50. Id. art. 32.
51. Id. art. 32.
52. Id. art. 33.

53. G.A. Res. 2200A, 21 U.N. GAOR, Supp. 16, at 49, U.N. Doc. A/6316 (1966). There were two Human Rights Covenants: one guaranteeing Economic, Social, and Cultural Rights, and the other Civil and Political Rights. All references in this Comment are to the latter. [hereinafter referred to as Human Rights Covenant].

54. U.N. CharTer, art. 1, para. 3.

55. Human Rights Covenant, art. 6.

56. Id. art. 7.

57. See M. Greenspan, The Modern LaW of Land Warfare 414 (1959).

58. U.S. Dep't OF the ARMY, The LAW of LAND Warfare If 5 (Field Manual No. 27-10, 1956) [heremafter cited as ARMY Manual]. The Army Manual specifically reiterates the corresponding rules of the Geneva Convention in ch. V, IT 246.350 . See Kunz, The New U.S. Army Field Manual on the Law of Land Warfare, 51 A.J.I.L. 388,390 (1957). 
the general consent of States." crime as "a violation of the law of war by any person or persons, military or civilian."

Thus, in a variety of ways the United States has indicated its unqualified support for international rules respecting humane treatment of civilians in war, and its willingness to be bound by these rules. It is now appropriate to apply these international principles to the apparent facts of the My Lai incident.

\section{II}

\section{APPLYING THE INTERNATIONAL RULES TO MY LAI}

Although arguably the civilian niassacre at My Lai was not a "crime against humanity," of nuurder, rape, sodomy, maiming and assault" hundreds of helpless men, women, and children clearly violated the "war crimes" section of the Nuremberg Charter, which prohibits "murder" and "wanton destruction". 83 Moreover, the Government's own indictment, which alleges that naass murders of civilians took place in violation of the Uniforin Code of Military Justice, ${ }^{64}$ indicates that the international law defense of "military necessity" is not applicable to My Lai.

It is similarly evident that the inhabitants of My Lai were not "humanely treated," but were subjected to such acts of violence as to

59. ARMY MANUAL $\{6$. The unanimous approval of the Human Rights Covenant by the more than 100 nations of the General Assembly would therefore make the Covenant binding upon the United States, despite the fact that the terms of the agreement have not as yet been officially ratified by this country. See also $\$ 1$ (c) of the Statute of the International Court of Justice, June 26, 1945, 59 Stat. 1031 (1945), T.S. No. 993 (effective Oct. 24, 1945), which includes within its definition of international law "the general principles of law recognized by civilized nations."

60. ARMY Manual, ch. VIII, If 499.

61. It is perhaps impossible to define the My Lai incident by itself as a crime against humanity, since these crimes require "huge and systematic actions." Ferencz, War Crimes Law and the Vietnam War, 17 AM. U.L. Rev. 403, 407 (1968).

62. N.Y. Times, Mar. 27, 1970, at 1, col. 2.

63. Charter of the International Military Tribunal, Aug. 8, 1945, art. 6(b), 59 Stat. 1547, E.A.S. No. 472,82 U.N.T.S. 286.

64. Art. 118, U.C.M.J., 10 U.S.C. \$ 918 (1964).

65. The defense of military necessity is applicable to rebut war crimes charges where the accused was compelled to act as he did by the exigencies of the military situation. See D'Amato, supra note 17, at 1099-1100. The fact that the Government has alleged mass murders of unarmed civilians at My Lai would indicate that the defense is inapplicable, unless the Umited States is to take the position that the killing of huge numbers of women and children is necessary to victory in Vietnam, a stance which is entirely inconsistent with the Administration's expression of shock and anger when the incident became public. See notes 103-06 infra and accompanying text. 
constitute a "grave breach" torture, corporal punishment . . . [and] other measures of brutality."07 In addition, statements of some of the soldiers present indicate that one of the aims of the My Lai attack was to "get revenge" for the deaths of several buddies who had fatally tripped enemy land mines in earlier combat operations. ${ }^{88}$ Thus, the American actions at My Lai may have violated Article 33 of the Geneva Convention, which expressly prohibits reprisals and collective penalties against any protected person "for an offense which he or she has not committed." ${ }^{\circ 9}$ It also appears that the My Lai assaults and killings may have deprived the victims of "humane treatment"70 as to constitute a "grave breach" of Article 27 of the Geneva Civilian Persons Convention.

Finally, the actions of U.S. soldiers at My Lai seem to have violated the Human Rights Covenant prohibitions of "inhuman [and] degrading punishment"11 and the guarantee of a basic civilian right to life. ${ }^{72}$ Thus, if the reported facts of the My Lai incident are substantially accurate, there exist express violations of the Nuremberg Charter, the Geneva Civilian Persons Convention, and the Human Rights Covenant rules against murder, brutal treatment, and reprisals against civilians; and nembers of the United States Army committed internationallyprohibited war crimes in connection with the events at My Lai.

III

\section{THE NEED FOR AN INTERNATIONAL INVESTIGATION}

There is currently no officially-constituted international criminal court that could authoritatively deliberate war crimes charges against the United States. ${ }^{73}$ Hence, if American soldiers did commit war crimes at My Lai, it remains necessary to determine low the available legal processes could most effectively deal with the incident.

The Nixon Administration has thus far rehed upon wholly national procedures and has apparently rejected suggestions that international

66. Only "grave breaches" of the Geneva provisions relating to the protection of civilians are specifically interdicted by the treaty. See Geneva Civilian Persons Convention, supra note 46 , art. 147.

67. Id. art. 32.

68. Hersh, supra note 1 , at 62 \& 63 .

69. Geneva Civilian Persons Convention, art. 33.

70. Id. art. 27.

71. Human Rights Covenant, supra note 53, at art. 7.

72. Human Rights Covenant, art. 6.

73. The advantages and handicaps such a hypothetical conrt would have are discussed in Kutner, Due Process of War: An Ad Hoc War Crimes Tribunal: A Proposal, 43 NOTRE DAME LAWYER 481 (1968). 
law be invoked. ${ }^{74}$ If war crimes occurred at My Lai, however, the Administration surely should not limit its response to measures which are wholly outside the international forum. Because of legal shortcomings inherent im the national procedures already undertaken, and because of the positive benefits that might flow from a wider and wholly impartial war crimes investigation, some type of international treatment of the My Lai incident seems desirable as a complement to the Government's individual prosecutions.

\section{A. The Government's Response}

\section{Jurisdictional Limitations}

Of the approximately 70 men who participated in the My Lai incident, only a handful have been indicted. ${ }^{75}$ The primary reason for this anomaly is not lack of evidence, but rather the jurisdictional limitations imposed upon military courts by the 1955 Supreme Court decision in United States ex rel Toth $v$. Quarles. ${ }^{76}$ That case concerned a soldier who was honorably discharged after Army service in Korea and had resumed civilian life in Pittsburgh. Five months after his discharge military authorities apprehended and indicted him for a murder allegedly cominitted while he was in Korea. At the time section 3(a) of the Uniform Code of Military Justice expressly provided for continuing military jurisdiction over any discharged person charged with committimg a serious crime not triable in a civilian court. ${ }^{77}$ Government attorneys maintained that this statute was a valid exercise of Congress's power to regulate the land and naval forces. ${ }^{78}$

The Court, however, found section 3(a) unconstitutional. Writing for the majority, Justice Black reasoned that, "any expansion of courtmartial jurisdiction like that in the 1950 Act necessarily encroaches on the jurisdiction of federal courts set up under Article III of the Constitution where persons on trial are surrounded by inore constitutional safe-

74. See note 23 supra.

75. See note 14 supra.

76. 350 U.S. 11 (1955).

77. Subject to the provisions of article 43 , any person charged with having committed, while in a status in which he was subject to this code, an offense against this code, punishable by confinement of five years or more and for which the person cannot be tried in the courts of the United States or any state or territory thereof or of the District of Columbia, shall not be reheved from amenability to trial by courts-niartial by reason of the ternnination of said status.

10 U.S.C. $\$ 803$ (a) (1964) (originally enacted as Act of May 5, 1950, ch. 169, 64 Stat. 109 (1950) and originally codified at 50 U.S.C. $\$ 553(\mathrm{a})$ ).

78. The Government relied on the Act as a valid exercise of power granted Congress in article I of the U.S. Constitution "to nuake rules for the government and regulation of the land and naval forces," as supplemented by the necessary and proper clause. 
guards than in military tribunals."79 Justice Black recoguized that at times if there could be no court-martial there would be no trial at all. But he concluded that if this were so, it was because Congress had "not seen fit to subject [ex-servicemen] to trial in federal district courts,"80 and he invited the Congress to do so. Possibly because of the enormous practical difficulties federal court jurisdiction would entail ${ }^{81}$ however, Congress has not passed the suggested legislation, and thus a vacuum exists in which some ex-servicemen whose crimes are not discovered until after discharge are forever immune to any American prosecution. $^{82}$

In the case of My Lai this means that despite the strong possibility of participation by others, only those who still have ties with the military can be prosecuted. Obviously, this considerably undermines the retributive value of the My Lai prosecutions. Moreover, the jurisdictional void also serves to weaken the deterrent force of the court-martial indictments, for a prospective war criminal can gamble upon getting out of the service before his crime is discovered and lie can be brought to task. With indications in the Peers Panel report ${ }^{83}$ and elsewhere ${ }^{84}$ that some atrocities never are fully reported, the chances of a short-term soldier escaping war crimes prosecution in this nanner appear to be real, indeed.

\section{Unfairness to the Principal Defendant: Prejudicial Pre-trial Publicity ${ }^{85}$}

Few of the milhons of Americans who saw the December 5, 1969, issue of Life can easily forget the terrifying photographs of defenseless people awaiting their execution at the hands of American troops. Fur-

\footnotetext{
79. 350 U.S. 11,14 (1955).

80. Id. at 21 .

81. See Willis, Toth v. Quarles-For Better or Worse?, 9 VaND. L. Rev. 534, 540 (1956).

82. Toth was fully reaffirmed by the Supreme Court in the landmark case of O'Callahan v. Parker, 395 U.S. 258, 263-65 (1969). It has been suggested that a military-civilian commission could be imstituted to try discharged soldiers. Articles 18 and 21 of the U.C.M.J. provide for legislation of the "common law of war." However, no sucb steps have been actually carried out with respect to the My Lai case. See N.Y. Times, Nov. 30, 1969, at 29, col. 1.

83. N.Y. Times, Mar. 27, 1970, at 1, col. 2.

84. In connection with the slaying of women and children at Sonthong village which gave rise to murder charges against five U.S. Marines (see note 37 supra), daily war commumiques listed no Marine Corps ground actions in that arca at the time of the incident. N.Y. Times, Feb. 27, 1970, at 1, col. 7.

85. For convenience, the issues of pre-trial publicity and command influence are here analyzed with respect to Lt. Calley, the Army's principal defendant. However, the arguments advanced would of course apply equally to any of the other defendants.
} 
thermore, accompanying the pictures was a stunning indictment of $\mathrm{Lt}$. Calley, a man who had yet to stand trial:

Men, women, children. Babies. And we all huddled them up. We made them squat down, and Lieutenant Calley came over and said, you know what to do with them, don't you? . . . And he left, and came back 10 to 15 minutes later, and said how come you ain't killed then yet? And I told him that I didn't think you wanted us to kill them, that you just wanted us to guard them. He said no, I want them dead. He stepped back about 10, 15 feet, and he started shooting them $\ldots . .^{86}$

The above statement not only appeared in the Life article, but was dramatically related by an ex-G.I. to newscaster Mike Wallace in a nationwide CBS-TV interview. ${ }^{87}$ Similarly incriminating stories were carried in virtually every current events publication. ${ }^{88}$ The massacre details were prominent newspaper and television topics for weeks, as the Court of Military Appeals refused to halt public discussion of the case. ${ }^{89}$ It seems clear that Lt. Calley's riglt to a "cliarge fairly made and fairly tried in a public tribunal free of prejudice, passion, excitement and tyrannical power"90 is in jeopardy. Because Lt. Calley is to receive a general court-martial, his guilt will be determined by a two-thirds vote of military men who, even with the trial judge's instructions to refrain from reading about the case, could not seemingly have remained isolated from the mass media's saturation of the public mind with the details of My Lai. Moreover, since both the sentence and the findings will be determined by layınen, there may be an even greater cliance of prejudice than in civilian trials. ${ }^{81}$

In Estes v. Texas ${ }^{22}$ the Supreme Court emphasized that the accused must be protected against prejudice by pre-trial publicity if there is even the "probability of unfairness." ${ }^{3}$ The Court attempted to concretize

86. LIFE, Dec. 5, 1969, at 42 .

87. See note 8 supra and accompanying text.

88. See, e.g., NeW YoRKeR, Dec. 20, 1969, at 27-29; Nation, Dec. 29, 1969, at 209; TIME, Dec. 5, 1969, at 23-24.

89. On Nov. 25, 1969, Lt. Calley's lawyers asked the military judge at Fort Benning for three orders: To prohibit witnesses from making public statements about the case; to instruct the military jurors to refrain from reading about the case; and to prohibit the news media from continuing to disseminate incriminating stories concerning the controversy. Judge Kennedy granted the first two requests, but refused to issue an injunction to the news media. The defense attorneys then petitioned the Court of Military Appeals for a ruling as to the third requested order. On Dec. 2, 1969, the Court of Military Appeals denied the defense plea in a memorandum opinion which declared that there was "no basis for the extraordinary rehief of curtailing future publications and speech." See N.Y. Times, Dec. 3, 1969, at 1, col. 2.

90. Chambers v. Florida, 309 U.S. 227, 236 (1940).

91. See Stewart, Trial by the Press, 43 Mitrtary L. Rev. 37, 39 (1969).

92. 381 U.S. 532 (1965).

93. Id. at 543. 
this rule by laying down specific procedures for dealing with pre-trial publicity in Sheppard $v$. Maxwell, ${ }^{94}$ where the defendant was bitterly assailed by a local press that unceasingly demanded a verdict of guilty in the alleged murder of his wife. The Court pointed out that the exclusion of evidence is "rendered meaningless when news media make it available to the public." Re Reversing the conviction, the Court held that the trial judge should lave taken more adequate precautions such as insulating witnesses and controlling the release of information. ${ }^{90}$ The Court went on to say that "[w]here there is a reasonable likelihood that prejudicial news prior to trial will prevent a fair trial, the judge should continue the case until the threat abates, or transfer it to another county not so permeated with publicity."07

Applying the Sheppard guidelines to the My Lai case, it seems clear that nothing could be achieved by a continuance or change of venue, for public saturation has reached througliout the United States. Further, the ineans used to disseminate the story have been so graphic as to discourage the lope that anything but a continuance of several years would dilute the impact of the inassacre upon the American conscience. It would appear that under the broad test of "probable prejudice," of his right to a fair trial.

Thus, if the Government continues to rely solely upon domestic processes to deal with the incident, My Lai may well be the case which illustrates Justice Douglas's warning that "[W]hen a community is thoroughly aroused about soine heinous crime . . . there might be no place to which the trial could be transferred to protect the accused."09

\section{Unfairness to the Principal Defendant: Unlawful Command Influence}

Yet another factor that clouds the indictment of Lt. Calley is "cominand influence." Article 37 of the Uniform Code of Military Justice provides:

No authority convening a ... court-martial, nor any other commanding officer, may censure, reprimand, or admonish the court or any member . . . thereof, with respect to the findings or sentence adjudged by the court, or with respect to any other exercise of its or his functions in the conduct of the proceeding. No person subject

94. 384 U.S. 333 (1966).

95. Id. at 360 .

96. Id. at 359 .

97. Id. at 363 .

98. See text accompanying note 93 supra.

-99. Douglas, The Public Trial and the Press, 33 Rocky MT. L. Rev. 1, 9 (1960). 
to this chapter may attempt to coerce or, by any unauthorized means, influence the action of a court-martial . . . in reaching the findings or sentence in any case . . . 100

Although most command influence cases decided by the Court of Military Appeals liave concerned prejudicial remarks or actions on the part of the officer who convenes the court-martial, ${ }^{101}$ it is quite clear that Congress intended, through Article 37, "to assure all im the military service an absolutely fair trial in whicl fimdings and sentence are determined solely upon the evidence, and free from all unlawful influence exerted by any military superior."102

Command influence is an issue in the My Lai case by virtue of the roles played by President Nixon as Commander in Chief, and by Stanley Resor, Secretary of the Army. During the critical pre-trial period, both commanders made strong statements condemning those responsible for the My Lai incident. For example, in a December 8, 1969, press conference, President Nixon himself called the event a "massacre", ${ }^{103}$ and a press release described it as "abhorrent to the conscience of all the American people."104 Secretary Resor, for his part, expressed his "shock and dismay"105 and gave assurances that the incident was "wholly unrepresentative" of United States military operations. ${ }^{106}$

It is understandable that President Nixon and Secretary Resor felt compelled to react strongly to the My Lai incident. Nevertlieless, their remarks carry the clear implication of a strong desire for punishment of the guilty parties, and may well affect the court's determination of the guilt or innocence of the accused. Even though the court members may not be consciously aware of the effect of the President's and Secretary's statements, in the area of command influence the court must condeinn "not only . . conscious and recognizable influences, but . . . unconscious ones as well."107 For, as command influence gives rise to a presumption of prejudice, ${ }^{108}$ the court is not only concerned with striking down instances of actual prejudice, but also with building public confidence in the nuilitary system through disapproving even the appearance

100. Art. 37, U.C.M.J., 10 U.S.C. § 837 (1964).

101. The officer who convenes the court-martial also determines the cases to be tried, selects the court, and appoints the trial judge and often defense counsel as well. He thus wields great potential power over the outcome of a particular case. See Note, Can Military Trials be Fair? 2 Stan. L. Rev. 547 (1950).

102. United States v. Navarre, 5 U.S.C.M.A. 32, 37, 17 C.M.R. 32, 37 (1954) (emphasis added).

103. N.Y. Times, Dec. 9, 1969, at 16, col. 1.

104. N.Y. Times, Nov. 27,1969 , at 1 , col. 8 .

105. N.Y. Times, Dec. 9, 1969, at 17, col. 3.

106. See note 10 supra.

107. United States v. Navarre, 5 U.S.C.M.A. 32, 41, 17 C.M.R. 32, 41 (1954).

108. United States v. Johnson, 14 U.S.C.M.A. 548, 551, 34 C.M.R. 328, 331 (1964). 
of impartiality. ${ }^{100}$ It would certainly appear that the statements of President Nixon and Secretary Resor may lead the military jurymen to conclude that the top brass desires the conviction of those charged as a as a way of clearing the name of the United States Army.

In addition to possible prejudice at the trial level because of the weight which the opimions of these two men could be naturally expected to carry within the Army hierarchy ${ }^{110}$ both the President and the Secretary of the Army may well become personally involved in approving the sentences handed down by the military jury. ${ }^{111}$ Because of the obvious political sensitivity of the case and the possibility of expressed or implied censure of upper-echelon Army policy-makers withm the Nixon Administration, the roles of President Nixon and Secretary Resor in the post-conviction sentencing process may amount to an unlawful "personal influence" over the outcome of the case. ${ }^{112}$ Their strong condemnation of the My Lai killings may exert at least an unconscious influence upon the "complete mental freedom"113 of the military jurors.

Fimally, it should be noted that the court's ultimate resolution of the command influence issue will be markedly influenced by the severity of the sentences handed down. ${ }^{114}$ Hence, the more severe the judgment of the military court in respect to Lt. Calley and his co-defendants, the greater the likelihood of a Court of Military Appeals reversal for unlawful command influence.

109. United States v. Fowle, 7 U.S.C.M.A. 349, 352, 22 C.M.R. 139, 142 (956).

110. The force of statements emanating from the highest reaches of the military command was alluded to in Fowle, where the military court members were made aware of a policy directive issued by the Secretary of the Navy. The court commented:

Although we are here faced with a secretary rather than a command directive, the former, emanating from the Secretary of a service, would be even more persuasive and bring more pressure to bear upon the members of the court than the latter type of directive.

Id. at 351, 22 C.M.R. at 141.

111. If Lt. Calley or his co-defendants receive the death sentence, the President must approve it. The Secretary of the Army must approve any sentence extending to dismissal of an officer. UNited States MaNual for Courts-Martial, $\pi 98$. (rev. ed. 1969), 34 Fed. Reg. 105a, 10669, (1969). See generally N.Y. Times, Dec. 9,1969 , at 17 , col. 2 .

112. See United States v. Hawthorne, 7 U.S.C.M.A. 293, 298, 22 C.M.R. 83, 88 (1956): "On the post-conviction level, we invalidated the proceedings when it appeared that the record of trial was reviewed by a person having a personal interest in the outcome of the litigation."

113. See United States v. Pierce, A.C.M. 16799, Pierce, 29 C.M.R. 849, (1960), an Air Force court-martial case, where the Board of Review concluded:

In all such cases wherein the court lias concluded that the views or statements of a higher autlority may have impinged upon the complete mental freedom of court members in the exercise of their responsibilities, disapproval has mexorably followed and reversive action directed.

29 C.M.R. at 850 (emphasis added).

114. See United States v. Wright, 17 U.S.C.M.A. 110, 113, 37 C.M.R. 374, 377 (1967). See also United States v. Johnson, 14 U.S.C.M.A. 548, 552, 34 C.M.R. 328, 332 (1964). 
Thus, while the Government's response to the My Lai incident through court-1nartial procedures is designed to punish the individuals directly responsible, it seems doubtful that this goal can be effectively accoinplished. The jurisdictional deficiencies imposed by the Toth case make even the indictment of more than a few soldiers impossible, and any convictions the Government might secure could well be reversed by a higher court on grounds of prejudicial publicity or unlawful command influence.

The possibihity that the My Lai indictments will deter future American violations of the laws of war seems unlikely. Of course, the average soldier will now at least be aware of the fact that he can be punished for carrying out an illegal order; yet, the psychological pressures to obey a superior order remain formidable, ${ }^{115}$ and will no doubt be even further strengthened by the likelihood that, for one legal reason or another, several of those who took part in the horrors of My Lai inay never be punished. It appears that truly effective deterrence of My Lai-type; atrocities will result only froin the Government's application of more far-reaching, less burdensome procedures, which will complement the military's mdividual adjudications of guilt with an intensive, impartial investigation of possible war crimes at every level of the military command. But the military court alone "will not be competent"116 to deal with this and other "vastly broader questions" which the My Lai incident suggests. It appears that the wide-ranging, extra-military fact-finding apparatus of an international body should be einployed as well. Some of the specific ways in which resort to the international forum could benefit the long-range goals of the United States will be examined in the following section.

\section{B. Potential Benefits of an International Investigation}

\section{Revitalizing International Laws Protecting Civilians}

Throughout recent history, the incidents of atrocities against civilians have become appallingly frequent. ${ }^{117}$ With terrifying weapons of destruction now in the hands of many belligerent countries, established international organizations are unable to force compliance with international law without vigorous support froin the great powers. ${ }^{118}$

Since World War II, the United States has proclaimed itself as a staunch supporter of international primciples. ${ }^{119}$ It has officially ap-

115. See notes 18-20 supra and accompanying text.

116. N.Y. Times, Dec. 10, 1969, at 54, col. 1 (editorial).

117. See notes 24-28 supra and accompanying text.

118. See note 29 supra.

119. See Pt. I supra. 
proved the Nuremberg Charter, the Geneva Civilian Persons Convention, and the United Nations Human Rights Covenant on Civil and Political Rights. The United States maintains military bases throughout the world as an ostensible deterrent to illegal aggression, and the State Department has invoked international law principles to support the heavy United States involvement in Vietnam. ${ }^{120}$ Moreover, the United States has publicly insisted upon United Nations application of the Prisoner of War provisions ${ }^{121}$ of the 1949 Geneva Convention to North Vietnam. ${ }^{122}$

Having invoked so frequently and forcefully the dictates of intcrnational law, the massacre at My Lai raises questions in the minds of other nations as to this country's resolve in its purported commitments to international humanitarian principles. ${ }^{123}$ Admittedly, the United States has shown good faith in the actions it has already taken with regard to the incident. But the seriousness of the My Lai charges, when coupled with a host of other reports of United States military personnel's cruelty toward Vietnamese civilians, ${ }^{124}$ seem so contrary to this country's professed attitude toward humanitarian principles as to require that the United States take every conceivable step to demonstrate that it ablors all acts of illegal violence toward civilians, and that it will act resolutely to ferret out and punish such international crimes at every level of the inilitary command network. If the United States, the leading postwar proponent of international justice, is to esclew the international forum when its own conduct is questioned, the credibility of international law as a means of punishing and deterring illegal abuses of civilians will be seriously undermined.

On the other liand, if the United States were to support the use of international inachinery in response to the My Lai incident, sucl a move would no doubt restore mucli of the fading respect for the laws of war, for it would convimce inany potential lawbreakers aniong the world's belligerent nations that the United States will lend its powerful support to the application of imternational safeguards protecting civilian lives, regardless of who is involved. With the reported incidents of atrocities growing daily, and with a profusion of bloody new wars of independence on the horizon, the need for an unqualified United States commitment to international law seems especially necessary in response to the My Lai incident.

120. See U.S. Dep't of State, The Legality of United States Participation in the Defense of Viet-Nam, 112 CoNG. REC. 5504, 5506 (1966).

121. Geneva Convention Relative to the Protection of Prisoners of War, Aug. 12, 1949, [1955] 3 U.S.T. 3316, T.I.A.S. No. 3364, 75 U.N.T.S. 135 [hereinafter referred to as Geneva Prisoner of War Convention].

122. Cf. N.Y. Times, Nov. 12, 1969, at 19, col. 1.

123. See note 31 supra, and accompanying text.

124. See notes 33-35 supra and accompanying text. 
In specific terms, the United States should demonstrate such a con1mitment to international humanitarian principles by opening up the international forum to an investigation of the massacre. For example, the United States should not continue to summarily dismiss or ignore charges that war crimes were committed at $\mathrm{My} \mathrm{Lai},{ }^{125}$ and it should carefully examine the possibility that such crimes occurred and were encouraged by the type of training and indoctrination policies which were inculcated into the minds of the men who took part in the My Lai killings. Unfortunately, such a re-evaluation of military methods is apparently beyond the scope of the present court-martial indictunents. ${ }^{126}$

In addition, the United States should do all within its power to allow for a United Nations investigation such as that conducted by the United Nations Committee on Human Rights into alleged Israeli violations of the Geneva Civilian Persons Convention. ${ }^{127}$ Since investigations by the Human Rights Committee require the prior consent of the parties involved, ${ }^{128}$ the United States could publicly declare that it approves of an investigation into the broadest aspects of the My Lai charges, and that it will abide by the recommendations of the Committee. Privately, American leaders could inform friendly nations that the United States will not react unfavorably to a motion by one of them to institute a human rights investigation into the incident, and this country could urge them to make an appropriate declaration to the United Nations. ${ }^{120}$

Of course, many will argue that it is unfair to expect such generous diplomatic advances by the United States when the enemy in Vietnam has also abused civilians. ${ }^{130}$ However, it would seem that even though American armed forces may not be the only ones to have violated the laws of humanity in Vietnam, America's stature as a world leader requires it to take the diplomatic mitiative by affirming its willingness to abide by the civilized rules of war. Admittedly, operating under such a diplomatic disadvantage may serve to weaken the overall United States position in Vietnam. However, it must be remembered that the power of the United States is sufficiently great that the actual security and territorial integrity of this country would not be greatly jeopardized by

125. See note 23 supra.

126. See note 21 supra and accompanying text.

127. See U.N. Doc. E/CN.4/AC.26/Rt.2. (1970).

128. See Starr, International Protection of Human Rights and the United Nations Covenants, 1967 WIS. L. REv. 863, 880.

129. Ten states, in addition to the parties directly involved in a particular dispute, nust declare that the United Nations Human Rights Committee will be competent to deal with the issues involved. Human Rights Covenant, supra note 53, art. 41.

130. For reports of North Vietnamese and Viet Cong atrocities against civilians, see generally LIFE, Sept. 3, 1965, at 28-33; TIME, May 10, 1968, at 37. 
diplomatic initiatives of the kind suggested, ${ }^{131}$ and that the great-power stature of the United States places upon it a very special responsibility for the control of war crimes im the international sphere.

In summary, extensive United States co-operation with an international My Lai investigation is a necessary complement to individual courts-martial, because the military and moral leadership which this country has proclaimed in the struggle for human rights throughout the world places an exceptionally strong burden upon the United States to squarely face the international implications of the My Lai charges. Positive action by the United States in the international sphere may hopefully deter all-too-frequent violations of international laws protecting civilians, and it will certainly serve to dramatically convince our allies in the Vietnam War that America will not tolerate atrocities agamst civihans in the pursuit of military goals. ${ }^{132}$ And finally, the revitalization of international humanitarian principles will inevitably have a beneficial effect upon those vital endeavors of the United States which depend to a great degree upon meaningful international co-operation. ${ }^{133}$

\section{Closing the Credibility Gap}

Although Secretary Resor has characterized the My Lai massacre as wholly unrepresentative of Army conduct, ${ }^{134}$ it is clear that even if it is isolated, the massacre would offer sufficient cause for a war crimes charge against the United States soldiers who were involved. ${ }^{135}$ There are strong indications, however, that the atrocities were not mere anomalies, but were a logical outgrowth of estabhished United States military tactics. Some questionable military practices and numerous reports

131. Cf. Falk, International Law and the United States Role in the Vietnam War, 75 YALE L.J. 1122 (1966).

132. Reports of apparent South Vietnamese violations of the most elemental international standards abound. Apparently the current government of the Republic of Vietnam has inflicted prolonged torture upon students who oppose the regime [See Morrow, Girls Story of Saigon Torture, S.F. Chronicle, May 13, 1970, at 8, col. 3], and has jailed political prisoners in "tiger cages" [N.Y. Times, July 7, 1970, at 3, col. 1]. Moreover, South Vietnamese troops reportedly looted Cambodian villages in sweeps through that country, raping and robbing at gunpoint as they went. N.Y. Times, July 2,1970 , at 8 , col. 1 .

Most disturbing is a recent report of an American doctor who said she had treated victins of beatings and torture inflicted in a Sonth Vietnamese "interrogation center." The victims, many of them woinen and children, were subjected to electric torture, the forced drinking of lime, and hanging upside-down for hours at a time. The center had an American advisor, and many of the detainees had been turned over by American troops. N.Y. Times, July 18, 1970, at 1, col. 6.

133. For example, the United States has recently suggested an international agrecment to eounter political terrorism. N.Y. Times, June 27, 1970, at 1, col. 6 . See note 122 supra and aceompanying text.

134. See note 8 supra and accompanying text.

135. See notes 61-75 supra and accompanying text. 
from reliable non-Governmental sources suggest that American military policy encourages or condones mistreatment of civilians. Thus, American policy-makers im Washington and commanders in Vietnam may themselves share responsibility for any war crimes committed in Vietnam, and specifically at My Lai.

In the first place, the Army designates entire areas of suspected enemy activity as "free fire zones," im which any person, regardless of sex or status, is automatically considered a Viet Cong sympathizer and can be killed at a soldier's virtually unbridled discretion. ${ }^{36}$ Moreover, United States military leaders encourage high "body counts" as evidence of war gains; some brigade commanders run contests in which privileges are awarded to coinpanies that register the most kills. ${ }^{137}$ Apparently, civilians are routinely mcluded in the statistics; one soldier indicated that the indiscriminate slaughter of women and children was "commonplace."138

Secondly, reports of various informed sources allege the use of torture, maiming, terror, and murder as relatively routine United States policies, ${ }^{139}$ and assert that license to commit such atrocities originates in "orders from higher up."140

Third, although the Government claims the contrary, some sources contend that the United States air war in Vietnain is conducted with utter disregard for civilian welfare. They cite the repeated American bombing attacks upon a Vietnamese leprosarium ${ }^{141}$ and upon the Huong Phuc school ${ }^{142}$ as examples of the targets pounded daily during the raids of North Vietnam. As to the policy in South Vietnam, two journalists who observed United States air strikes at first hand suggest a possible link between American bombing strategy and the My Lai massacre. They offer the following explanation of how the Army's purposeful boinbing of civilian targets interacted with American pacification $^{143}$ policies to produce an official climate of imdifference to civilian

136. Some soldiers apparently make sport of stalking and killing Vietnamese civilians in free-fire zones. Hersh, supra note 1 , at 55. The entire province in which My Lai hamlet was situated had been classed as a free-fire zone, on the basis of "prominent enemy activity." Id.

137. Id.

138. Id. at 56.

139. See notes 33-36, 38 supra and accompanying text.

140. See statement of correspondent Ralph Schoenman, N.Y. Times, Nov. 30, 1969, at 30 , col. 3 .

141. The leprosarium at Quyn Lap was the targct of 39 separate bombing missions which, according to the North Vietuamese statistics, demolished 160 buildings which housed over 2,000 lepers. M. MCCARTHY, HANOr 28 (1968).

142. Children on their way to school were reportedly mutilated and buried alive. See Schoeninan, Report from North Vietnam, appearing in Appendix to B. RUSSELL, War CRIMES IN VIETNAM 135 (1967).

143. A najor objective of the American pacification program is to make the civilian 
lives and property:

In August, 1967, during Operation Benton, the "pacification" camps became so full that Army units in the field were ordered not to "generate" any more refugees. The Army complied. But search and destroy operations continued. Only now peasants were not warned before an airstrike was called in on their village. They were killed in their villages because there was no room for them in the swamped pacification camps. The usual warnings by helicopter loudspeaker or air dropped leaflets were stopped . . . . Village after village was destroyed fron the air as a niatter of de facto policy. Airstrikes on civilians became a natter of routine. It was under these circuinstances of official acquiescence to the destruction of the countryside and its people that the massacre of Songmy occurred. ${ }^{144}$

A final contention that the My Lai massacre may not have been an isolated incident is provided by Seymour Hersh's report that Lt. Calley's platoon had been engaging in atrocities even before the My Lai operation began. Apparently the unit liad begun abusing civilians in Song My Province as early as February 15, 1968, with the beating and murdering of an old man, and later episodes included the rape and murder of a mother and the killing of her baby. ${ }^{145}$

Other reports of United States Army atrocities against civilians can be found elsewhere. ${ }^{146}$ Together they are enough to suggest that the My Lai massacre was not an isolated mcident, but was in large ineasure the result of official actions that instilled in the average soldier a disregard for the sanctity of civilian life.

The possibility of a connection between My Lai and established United States policy is simply too strong to be ignored. A determination of the extent of any nexus between My Lai and the total American

population safe from Communist attacks. It is claimed that, in effect, this requires the placing of huge numbers of civilians in barbed-wire enclosed camps after depriving them of their possessions. (B. Russele, War Crimes IN Vietnam 60 (1967)), and that as a result of two years of Ainerican operations in Quang Ngai (Songmy) province, where the My Lai massacre took place, 138,000 civilians were made homeless and $70 \%$ of the houses and huts were destroyed by bombs, shells or fire. HERSH, supra note 1, at 54 .

144. Letter from O. \& J. Schell to the Editor of the N.Y. Tines, Nov. 26, 1969, at 44 , col. 3 .

145. Hersh, supra note 1, at 61. According to Ron Grzesik, a G.I. in Lt. Calley's platoon:

It was tike going from one step to another, worse one . . . . First, you'd stop the people, question thein, and let them go. Seeond you'd stop the people, beat up an old man, and let them go. Third, you'd stop the people, beat up an old man, and then shoot him. Fourth, you go in and wipe out a village.

Id. at 63 .

146. See, e.g., B. Russell, supra note 33; D'Amato, supra note 17. 
war effort would provide a significant insight into the reliability of those unofficial reports that have furnished extensive evidence of United States war crimes-reports which have been virtually ignored by military authorities. ${ }^{147}$ My Lai, the first instance of an officially admitted United States atrocity against civilians, furnishes an ideal factual context in which the American public can examine the extent to which our basic mihtary goals in Vietnam conflict with other, perhaps more vital national interests, such as the observance of humanitarian principles in American conduct toward the Asian civilians who are unfortunately caught up in the war.

The Administration's isolated-incident treatment of the My Lai massacre precludes the far-reaching factual inquiry which would inevitably result from an international investigation into the incident, for the prosecution of a war crimes charge, unlike a conventional inurder prosecution, requires comprehensive factual evidence concerning the degree to which higher officials may have been indirectly responsible for the allegedly illegal acts. ${ }^{148}$

Furthermore, investigation by a purely American body such as a cominittee of the United States Congress, even if it did reach the broad issue of the legality of basic United States policies, ${ }^{149}$ would be tainted at the outset by the possibility that the bias of individual legislators, nearly all of whom have already made some public cominitment on the war issue, would color the ultimate findings of fact. ${ }^{150}$ With feelings on the war so thoroughly polarized throughout America, it seems doubtful whether any American investigator, regardless of his diligence and good faith, could successfully convince the public that his findings were not influenced by personal bias.

Since maximum impartiality on the part of the fact-finder is an essential ingredient in a publicly credible investigation, ${ }^{151}$ it would there-

147. See note 38 supra and accompanying text.

148. See the section of the Nuremberg Charter relating to conspiracy by "leaders and organizers." Charter of the International Military Tribunal, Aug. 8, 1945, 59 Stat. 1547, E.A.S. No. 472, 82 U.N.T.S. 284 (quoted im text accompanying note 42 supra).

149. The My Lai investigation conducted by a special four-man House Armed Services Investigating Subcomınittee, while it did stress the Army's poor handling of the case, did not make specific findings with regard to the legality of overall United States policies. See N.Y. Times, July 15, 1970, at 17, col. 1 .

150. The credibility problems faced by congressional investigations into the explosive Vietnam issue, is exemplified by the report of the House Select Committee on Southeast Asia, which toured the war zone in Indochina to investigate prison conditions. A staff member himself angrily charged that, because of political considerations, the Committee had suppressed significant findings and engaged in a "whitewash." N.Y. Times, July 8, 1970, at 1 , col. 3 .

151. Credibility of the facts uncovered by an investigation is ordinarily directly proportional to faith in the impartiality of the fact-finders as perceived by all parties 
fore appear that some disinterested international party, such as the United Nations, ${ }^{152}$ would be ideally suited to such a task. Perhaps the best choice would be an investigation under the auspices of the Special Working Group of Experts, which has been established under Resolution 6 (XXV) of the United Nations Commission on Human Rights, ${ }^{153}$ and which has recently reported to the General Assembly the results of a thorough study of Israeli violations of the Geneva Civilian Persons Convention. ${ }^{154}$ Any sister signer of the Geneva Convention could bring the appropriate charges against the United States. However, such an alternative requires bold international initiatives ${ }^{\mathbf{1 6 5}}$ on the part of the United States; initiatives which have so far been lacking in the Government's response to the My Lai mcident.

\section{CONCLUSION}

According to all applicable treaties and international precepts, nembers of the United States armed forces appear to have committed war crimes against the civilian population of My Lai. Although the United States acknowledges, in general, the applicability of international humanitarian rules to its conduct in Vietnain, ${ }^{166}$ the present Administration has eschewed the international war crimes issue in its response to the My Lai massacre. This failure to bring the question of American mistreatment of civilians squarely before an inipartial international body inust inevitably: First, result in the use of legal procedures which are largely ineffective both as retributive and deterrent measures; second, produce doubt in the world as to the strength of the United States coinmitment to even-handed international justice and general humanitarian principles; and third, leave unresolved vital factual disputes as to whether the My Lai massacre was a logical outgrowth of basic United

to the dispute. Franck \& Cherkis, The Problem of Fact-Finding in International Disputes, 18 WEST. RES. L. REV. 1483, 1523 (1967).

152. Choosing the Red Cross International for such a controversial investigation might be undesirable as that body, to remain effective, must avoid taking sides, lest its integrity and universahty be threatened. See J. JoYCE, THE Red Cross International AND the Strategy of Peace 214 (1959).

153. This ad hoc group of experts has powers to call upon the parties for relevant information and to make reports of its findings. It was first used to investigate reports of torture and ill treatment of prisoners and persons in police custody in South Africa. Res. 2(XXIII), quoted in Commission on Human Rights, Report on the Twenty-third Session, U.N. Doc. E/4322 E/CN.4/940, at 76 (1967). The group also is aware of the need for evaluation of evidence [See U.N. Doc. E/CN.4/AC.22/SR.6 (prov.) at 26-27 (1967)], and is entitled to go beyond governunental reports and to examine the reports of non-governmental sources and the testimony of witnesses.

154. See note 127 supra and accompanying text.

155. For suggestions of steps the United States unight take in the international sphere with regard to My Lai, see notes 128 \& 129 supra and accompanying text.

156. See notes $47,58-60$ supra and accompanying text. 
States policies in Southeast Asia that are violative of the laws protecting civilian populations.

An international war crimes investigation would deal with these sweeping issues, and would provide the broad, impartial fact-finding procedures needed to place the My Lai tragedy in the perspective of overall United States military operations in Vietnam. If such an investigation were to exonerate the United States citizens of war crimes charges, this would serve to dispel many of the reports and rumors that have caused serious doubts about the propriety and legality of American military policies in Southeast Asia. If, however, a war crimes investigation were to uncover specific United States policies that are violative of international law, this finding would enable the American public to intelligently evaluate these policies, and might cause sufficient public condemnation of illegal practices as to effectively deter the commission of future war crimes in the name of America.

Finally, it is possible that an international investigation into the My Lai incident would reveal that civilian atrocities are the natural and inevitable result of a war policy that requires massive air, ground, and chemical attacks upon an enemy often indistinguishable from the civilian population at large. In this sense, not only United States activities in Vietnam, but as well those directed against countries similarly situated-for example Cambodia and Laos-would be immediately suspect or outrightly condemned as a matter of international law. Even if official American acceptance of such a rationale is only remotely possible, with the Southeast Asia war effort becoming every day more politically and economically costly, an Administration could view such a finding as a noble pretext for extricating itself from the Indochina war without waiting further for the "honorable peace" that las proved so elusive.

As long as the Government's response to My Lai stops short of an international war crimes investigation, however, and remains limited to military administrative sanctions and conventional criminal indictments of a handful of infantrymen, one can only gloomily predict that there will be more trials like the upcoming one at Fort Benning. 